\title{
KEWENANGAN PENGADILAN AGAMA DALAM PENGANGKATAN MEDIATOR NON HAKIM BERDASARKAN PERMA NOMOR 1 TAHUN 2016
}

\author{
Qurratul A’yuni, Akhmad Muslih, Amancik.
}

\begin{abstract}
ABSTRAK
Adapun tujuan penelitian ini: (1) Untuk mengetahui dan menganalisis kewenangan pengadilan agama dalam pengangkatan mediator non hakim berdasarkan PERMA Nomor 1 Tahun 2016 Tentang Prosedur Mediasi di Pengadilan. (2). Untuk mengetahui dan menganalisis hambatan pengangkatan mediator non hakim terhadap penyelesaian perkara pada pengadilan agama. Pada metode penelitian tesis ini, jenis penelitian ini termasuk dalam kategori penelitian hukum yang bersifat yuridis normatif. Pada ada penelitian ini ada empat pendekatan yang digunakan yaitu; Pendekatan peraturan perundang-undangan (statute approach), Pendekatan Kasus (case approach), dan Pendekatan Konseptual (conceptual approach), serta Pendekatan Perbandingan (comparative approach). Hasil penelitian bahwa: (1). Kewenangan Pengadilan Agama dalam pengangkatan mediator non hakim pada Berdasarkan Peraturan Mahkamah Agung Nomor 1 Tahun 2016 Tentang Prosedur Mediasi Di Pengadilan, pada dasarnya yang menjadi mediator adalah orang yang bukan hakim yang telah mendapat dan memperoleh sertifikat mediator dari lembaga yang sudah terakreditasi oleh MA, akan tetapi PERMA Nomor 01 Tahun 2008 memberikan kelonggaran apabila disuatu lingkungan peradilan tidak terdapat mediator bersertifikat maka yang menjadi mediator adalah hakim yang berada dalam lingkungan peradilan tersebut. Prinsip utama untuk pengangkatan mediator adalah harus memenuhi persyaratan kemampuan personal dan persyaratan yang berhubungan dengan masalah sengketa para pihak. Jika persyaratan ini telah di penuhi baru mediator dapat menjalankan mediasi. (2). Hambatan pengangkatan mediator terhadap penyelesaian perkara Pengadilan Agama, ada dua yakni; pertama, akan berhasil jika terpenuhi empat hal mengenai keberhasilan mediasi yaitu; para pihak, mediator, keluarga, advokat (jika memakai advokat). Kedua, bisa gagal jika para pihak sudah tidak ingin berdamai dan rukun kembali. Karena para pihaklah yang mengambil keputusan, berdamai atau tidak. Sebagai pihak yang netral mediator memiliki peran penting dalam proses mediasi.yang membantu para pihak dalam proses perundingan guna mencari berbagai kemungkinan penyelesaian sengketa tanpa menggunakan cara memutus atau memaksakan sebuah penyelesaian.
\end{abstract}

Kata Kunci: Kewenangan, Pengadilan Agama, Pengangkatan Mediator Non Hakim. 


\section{A. PENDAHULUAN}

\section{Latar Belakang Penelitian}

Di Indonesia sesuai dengan

Pasal 24 Undang-Undang Dasar

Tahun 1945 menjelaskan bahwa:

(1) Kekuasaan Kehakiman merupakan kekuasaan yang merdeka untuk menyelenggarakan

peradilan guna menegakkan hukum dan keadilan.

(2) Kekuasaan kehakiman dilakukan oleh sebuah Mahkamah Agung dan badan peradilan yang berada di bawahnya dalam lingkungan peradilan umum, lingkungan peradilan agama, lingkungan peradilan militer, lingkungan peradilan tata usaha negara, dan oleh sebuah Mahkamah Konstitusi.

(3) Badan-badan lain yang fungsinya berkaitan dengan kekuasaan kehakiman diatur dalam undang-undang.

Berdasarkan penjelasan di atas berwenang memeriksa dan mengadili sengketa hanyalah badan peradilan yang bernaung dibawah kekuasaan-kekuasaan kehakiman yang berpuncak pada Mahkamah Agung Republik Indonesia. Berdasarkan Undang-Undang Nomor 3 Tahun 2006 tentang Perubahan Undang-undang Nomor 7 Tahun 1989 yang telah diubah dengan Undang-undang Nomor 50 Tahun 2009 Tentang Peradilan Agama bahwa yang berwenang menyelesaikan sengketa ekonomi syariah adalah Pengadilan Agama.

Secara normatif, mediasi berdasarkan Peraturan Mahkamah Agung Nomor 1 Tahun 2016 tentang Prosedur Mediasi di Pengadilan dalam Pasal 1 ayat (1) didefinisikan sebagai berikut:

Mediasi adalah cara penyelesaian sengketa melalui proses perundingan untuk memperoleh kesepakatan Para Pihak dengan dibantu oleh Mediator.

Mediasi merupakan cara penyelesaian sengketa yang atas kesepakatan para pihak yang bersengketa melibatkan pihak ketiga yang netral sebagai mediator dalam rangka mempercepat tercapainya perdamaian.melalui mediator diyakini akan mampu mengarahkan para pihak menuju perdamaian lebih cepat. ${ }^{1}$ Untuk ketentuan mediator di Pengadilan selanjutnya diatur Pada Pasal 1 angka (2) PERMA Nomor 1 Tahun

\footnotetext{
Candra Irawan, Aspek Hukum Dan Mekanisme Penyelesaian Sengketa Di Luar Pengadilan (Alternative Dispute Resolution) Di Indonesia, Mandar Maju, Bandung, 2010, HIm42.
} 
2016 tentang Prosedur Mediasi Di

Pengadilan dijelaskan bahwa;

Mediator adalah Hakim atau pihak lain yang memiliki Sertifikat Mediator sebagai pihak netral yang membantu Para Pihak dalam proses perundingan guna mencari berbagai kemungkinan penyelesaian sengketa tanpa menggunakan cara memutus atau memaksakan sebuah penyelesaian.

Berdasarkan PERMA Nomor 1

Tahun 2016 tentang Prosedur Mediasi di Pengadilan mengatur peran mediator dalam mediasi. Namun, kenyataannya hal ini sering tidak dianggap penting dan cenderung diabaikan sehingga mediasi sering tidak berhasil dan sengketa pada akhirnya diselesaikan dengan jalur litigasi. Di dalam PERMA Nomor 1 Tahun 2016 ini, lebih memberi penekanan kepada peran Mediator dalam proses mediasi.

Berdasarkan PERMA inilah Mediator harus memiliki keterampilan negosiasi dan mampu mencari teknik-teknik yang paling sesuai apabila para pihak sudah tidak menemukan lagi jalan keluar untuk menyelesaikan sengketa tersebut. Disinilah terlihat jelas peran penting Mediator. Namun, data empiris menunjukan bahwa peran penting

mediator belum terlalu efektif dilaksanakan, sebagaimana beberapa hasil penelitian, salah satunya hasil penelitian dari Subiarti, dimana peran mediator dalam penyelesaian sengketa ekonomi syariah secara keseluruhan belum optimal dikarenakan adanya beberapa hambatan yang dihadapi mediator, yaitu mediator belum memiliki sertifikat mediator dan belum mengikuti pelatihan ekonomi syariah sebagai bidang baru kewenangan Pengadilan Agama.

\section{Identifikasi Masalah}

Berdasarkan latar belakang
diatas, maka yang menadi
identifikasi dalam penelitian ini
adalah sebagai berikut:
a. Bagaimana kewenangan
pengadilan agama dalam
pengangkatan Mediator
Non Hakim berdasarkan
PERMA Nomor 1 Tahun
2016 tentang Prosedur
Mediasi di Pengadilan?
Bagaimana hambatan
pengangkatan Mediator
Non Hakim terhadap
penyelesaian perkara di
Pengadilan Agama?




\section{B. METODE PENELITIAN}

\section{Jenis Penelitian}

Berdasarkan uraian latar belakang dan identifikasi masalah dalam bab sebelumnya, maka jenis penelitian ini termasuk dalam kategori penelitian hukum yang bersifat yuridis normatif. Penelitian normatif ini yang diteliti adalah bahan pustaka atau data sekunder yang mencakup bahan hukum primer, bahan hukum sekunder dan bahan hukum tersier. ${ }^{2}$

\section{Pendekatan Penelitian}

Pada ada penelitian ini ada empat pendekatan yang digunakan yaitu; Pendekatan peraturan perundang-undangan (statute approach), Pendekatan Kasus (case approach), dan Pendekatan Konseptual (conceptual approach), serta Pendekatan Perbandingan (comparative approach).

\section{Sumber Bahan Hukum}

Sumber bahan hukum yang digunakan untuk melengkapi data penelitian ini meliputi bahan hukum primer, sekunder dan bahan hukum tersier.

\section{Prosedur Pengumpulan Bahan Hukum}

${ }^{2}$ Soerjono Soekanto, Pengantar Penelitian Hukum, UI Press, Jakarta, 1986, hlm10.
Bahan hukum yang diperoleh dalam penelitian ini berupa bahan hukum primer dan bahan hukum sekunder serta bahan hukum tersier, maka teknik pengumpulan data yang digunakan adalah melalui studi dokumentasi atau melalui penelusuran literatur yang berhubungan dengan penelitian, yaitu dengan mengumpulkan dan mempelajari buku-buku, peraturan perundangundangan yang berkaitan dengan penelitian, makalah-makalah, hasilhasil penelitian serta bahan-bahan hukum yang tersedia di media internet.

\section{Analisis Bahan Hukum}

Setelah dilakukan pengumpulan bahan hukum baik berupa bahan hukum primer, sekunder maupun bahan hukum tersier. Data yang diperoleh dari studi kepustakaan dilakukaan analisis yuridis kualitatif yang disajikan dalam bentuk deskriptif dengan memberikan gambaran atau pemaparan atas subjek dan objek penelitian sebagaimana hasil penelitian yang dilakukan yaitu dengan menggambarkan peraturan perundang-undangan yang berlaku dikaitkan dengan teori-teori hukum dan praktek pelaksanaan hukum 
positif menyangkut permasalahan yang akan dibahas.

\section{HASIL DAN PEMBAHASAN}

1. Kewenangan Pengadilan Agama Dalam Pengangkatan Mediator Non Hakim Berdasarkan Peraturan Mahkamah

Agung Nomor 1 Tahun 2016 Tentang Prosedur Mediasi Di Pengadilan

Pengadilan sebagai salah satu instrumen penegak hukum telah memulai mediasi sejak 2008. dan disebut mediasi peradilan. Setiap perkara perdata yang mengajukan di harus melalui media mediasi. Mediasi dilakukan oleh mediator hakim dan mediator non hakim yang telah mengikuti Pendidikan Khusus Profesi Mediator (PKPM) yang diselenggarakan oleh lembaga yang sudah terakreditasi oleh Mahkamah Agung. Dalam melaksanakan tugas dan fungsinya mereka harus menunjuk ketentuan Peraturan Mahkamah Agung Nomor 1 Tahun 2016 tentang Prosedur Mediasi di Pengadilan (selanjutnya ditulis PERMA Nomor 1 Tahun 2016) dan Pedoman Mediator yang dibuat oleh Mahkamah Agung.

Proses mediasi di pengadilan dilakukan oleh seorang mediator yang berasal dari unsur hakim dan nonhakim. Mediator Non Hakim adalah mediator yang diambil dari unsur masyarakat di luar pengadilan. Seorang yang menjalankannya fungsi sebagai mediator harus memiliki sertifikat yang diperoleh setelah mengikuti Pendidikan Khusus Profesi Mediator (PKPM) yang diselenggarakan oleh lembaga yang terakreditasi oleh Mahkamah Agung. Namun PERMA Nomor 1 Tahun 2016 mengatur pengecualian bahwa jika dalam wilayah pengadilan tidak ada hakim yang bersertifikat, maka hakim di lingkungan pengadilan tersebut dapat berfungsi sebagai mediator. Dengan demikian maka bagi hakim yang tidak/belum bersertifikat pun dapat menjalankan fungsi mediator.

Pada teknis pelaksanaannya, hampir semua hakim di pengadilan bertindak sebagai mediator. Ketua pengadilan harus menunjuk dan mencantumkan nama-nama mediator sekurang-kurangnya 5 (lima) mediator. Hal ini dimaksudkan untuk memungkinkan proses mediasi untuk proses mediasi, yaitu sebagai tugas untuk proses litigasi. Tujuan lain dari semua ini adalah untuk mempermudah para pihak yang berperilaku memilihnya sebagai 
mediator untuk menyelesaikan perkenalan. Khusus untuk perkara ekonomi syariah dan waris, sebagian besar Pengadilan Agama di Indonesia masih belum mempercayakan mediasi kepada Mediator Non Hakim.

Hakim Mediator adalah Hakim yang menjalankan tugas untuk melakukan proses Mediasi setelah ada penunjukan dari ketua majelis Hakim atau diminta langsung oleh para pihak untuk menjadi Mediator bagi mereka. Hal ini sesuai dengan ketentuan dalam Pasal 19 ayat (1) PERMA Mediasi bahwa para pihak berhak memilih seseorang atau lebih Mediator yang tercatat dalam daftar Mediator di Pengadilan dengan ketentuan bahwa Hakim Mediator tersebut bukan lah Hakim yang menangani perkara yang sedang dimediasi, akan tetapi Hakim lain yang tidak memiliki keterkaitan dengan perkara yang sedang diperikasa.

Seperti halnya Hakim Mediator, Mediator yang berasal dari pihak luar yang ditunjuk oleh para pihak untuk memediasikan perkara mereka harus memiliki keterampilan khusus dalam bidang penyelesaian sengketa melalui mediasi yang dibuktikan dengan sertifakat
Mediator yang telah dikeluarkan oleh lembaga yang telah mendapat akreditasi dari Mahkamah Agung RI. Berdasarkan PERMA Mediasi terdapat tiga golongan yang yang dapat menjadi Mediator yang berasal dari kalangan non Hakim, yaitu:

1. Advokat;

2. Akademisi Hukum;

3. Profesi non hukum yang dianggap menguasi pokok sengketa.

Menurut PERMA Nomor1

Tahun 2016 Tentang Prosedur Mediasi Di Pengadilan dalam Pasal 13 disebutkan bahwa syarat utama bagi seorang Mediator baik Mediator Hakim maupun non Hakim ialah harus memiliki Sertifikat Mediator yang diperoleh setelah mengikuti dan dinyatakan lulus dalam pelatihan sertifikasi Mediator yang diselenggarakan oleh Mahkamah Agung atau lembaga yang telah memperoleh akreditasi dari Mahkamah Agung.

Dalam Peraturan Mahkamah Agung Nomor 1 Tahun 2008 tentang prosedur mediasi di Pengadilan pasal 1 ayat (6) menyebutkan, "Mediator adalah pihak netral yang membantu para pihak dalam proses perundingan guna mencari berbagai kemungkinan penyelesaian sengketa tanpa 
menggunakan cara memutus atau memaksakan sebuah penyelesaian".

Mediator yang dimaksud dalam PERMA ini adalah mediator yang menjalankan tugasnya pada Pengadilan. Mediator yang bertugas pada Pengadilan dapat saja berasal dari Hakim Pengadilan atau Mediator luar pengadilan. Hakim mediator adalah hakim yang menjalankan tugas mediasi atas penunjukan Hakim Ketua Majelis dan mendapat surat keputusan (SK) dari Ketua Pengadilan.

\section{Hambatan}

Pengangkatan

Mediator non Hakim Terhadap Penyelesaian Perkara Pengadilan Agama

Berdasarkan Pasal 4 ayat (1) Peraturan Mahkamah Agung (PERMA) Nomor 1 Tahun 2016 tentang Prosedur Mediasi di Pengadilan, maka jenis perkara yang wajib dilakukan mediasi adalah semua sengketa perdata yang diajukan ke Pengadilan termasuk perkara perlawanan (verzet) atas putusan verstek dan perlawanan pihak berperkara (partij verzet) maupun pihak ketiga (derden verzet) terhadap pelaksanaan putusan yang telah berkekuatan hukum tetap.

Proses mediasi di pengadilan dilakukan oleh seorang mediator yang berasal dari unsur hakim dan nonhakim. Mediator Non Hakim adalah mediator yang diambil dari unsur masyarakat di luar pengadilan. Seorang yang menjalankannya fungsi sebagai mediator harus memiliki sertifikat yang diperoleh setelah mengikuti Pendidikan Khusus Profesi Mediator (PKPM) yang diselenggarakan oleh lembaga yang terakreditasi oleh Mahkamah Agung. Namun PERMA Nomor 1 Tahun 2016 mengatur pengecualian bahwa jika dalam wilayah pengadilan tidak ada hakim yang bersertifikat, maka hakim di lingkungan pengadilan tersebut dapat berfungsi sebagai mediator. Dengan demikian maka bagi hakim yang tidak/belum bersertifikat pun dapat menjalankan fungsi mediator.

Pada teknis pelaksanaannya, hampir semua hakim di pengadilan bertindak sebagai mediator. Ketua pengadilan harus menunjuk dan mencantumkan nama-nama mediator sekurang-kurangnya 5 (lima) mediator. Hal ini dimaksudkan untuk memungkinkan proses mediasi untuk proses mediasi, yaitu sebagai tugas untuk proses litigasi. Tujuan lain dari semua ini adalah untuk mempermudah para pihak yang berperilaku memilihnya sebagai 
mediator untuk menyelesaikan perkenalan. Khusus untuk perkara istilah ekonomi syariah dan waris, sebagian besar Pengadilan Agama di Indonesia masih belum mempercayakan mediasi kepada Mediator Non Hakim.

Bahkan khusus untuk sistem ekonomi syariah, baik mediasi maupun pemeriksaan perkenalan oleh Majeis Hakim Tersendiri yang telah mengikuti pelatihan sutu ekonomi syariah. Syarat menjadi mediator adalah telah bersertifikat melalui pelatihan teknik mediasi dilakukan lebih sistematis, terutama dalam menggali interest dan need pihak berperkara. Penyelesaian perkara berbasis pada dua hak tersebut, bukan berbasis pada posisi (positions). Dengan cara ini maka interest dan need akan mudah ditangkap sehingga dapat digeser untuk mencari pilihan-pilihan yang win-win solution. Keuntungan lain bagi Pengadilan Agama dengan menggunakan Mediator Non Hakim adalah para hakim tidak terbebani oleh tugasnya sebagai mediator. mediasi merupakan tugas tambahan bagi hakim dan justru dapat mengakibatkan penumpukan perkara, serta berdampak proses mediasi dilakukan oleh beberapa hakim dalam waktu yang singkat, dan terkesan sebagai formalitas untuk memenuhi ketentuan Pasal 2 PERMA Nomor 1 Tahun 2016. Mediator memiliki peranan yang sangat penting dalam membantu para pihak dalam menyelesaiakan sengketa yang mereka hadapi. Terutama dengan peran pentingnya yang mendiagnosis konfik yang terjadi sehingga dapat mengidentifikasi masalah dan mengetahui akan kepentingan para pihak. Oleh sebab itu peranan dari Mediator bukan hanya sebagai penengah yang hanya bertindak sebagai penyelenggara dan pemimpin diskusi belaka, namun harus membatu para pihak untuk menemukan jalan keluar penyelesaian sengketa atas dasar kesepakatan bersama, sehingga para pihak tidak ada yang merasa dirugikan.

Pasal 14 PERMA Nomor 1 Tahun 2016 Tentang Mediasi menyebutkan bahwa dalam menjalankan fungsinya, Mediator memiliki tugas sebagai berikut:

1. Memperkenalkan diri dan memberikan kesempatan kepada para pihak untuk saling memperkenalkan diri; 
2. Menjelaskan maksud, tujuan, dan sifat mediasi kepada para pihak;

3. Menjelaskan kedudukan dan peran mediator yang netral dan tidak mengambil keputusan;

4. Membuat aturan pelaksanaan mediasi bersama para pihak;

5. Menjelaskan bahwa mediator dapat mengadakan pertemuan dengan satu pihak tanpa kehadiran pihak lainnya (kaukus);

6. Menyusun jadwal mediasi bersama para pihak;

7. Mengisi formulir jadwal mediasi;

8. Memberikan kesempatan kepada para pihak ntuk menyampaikan

permasalahan dan usulan perdamaian;

9. Menginventarisasi

permasalahan dan mengagendakan pembahasan berdasarkan skala prioritas;

10. Memfasilitasi dan mendorong para pihak untuk; 1. Menelusuri dan menggali kepentingan para pihak; 2. Mencari berbagai pilihan penyelesaian yang terbaik bagi para pihak; dan 3. Bekerja sama mencapai penyelesaian;

11. Membantu para pihak dalam membuat dan merumuskan kesepakan perdamaian.

Mediator sebagai penengah dalam suatu proses mediasi mempunyai fungsi tersendiri sebagai seorang mediator. Fungsi yang dimaksud adalah sebagai berikut:

1. Memperbaiki kelemahan komunikasi antara para pihak yang biasanya ada hambatan dan sekatsekat pikologis.

2. Mendorong terciptanya suasana yang kondusif untuk memulai negosiasi yang fair.

3. Secara tidak langsung mendidik para pihak atau memberi wawasan tentang proses dan substansi negosiasi yang sedang berlangsung.

4. Mengklarifikasi masalahmasalah substansial dan kepentingan masing masing para pihak. 
Berkaitan dengan peran dan fungsi mediator yang sangat penting dalam proses mediasi di Pengadilan Agama, Mahkamah Agung diharapkan dapat segera mengadakan pelatihan-pelatihan untuk para hakim di Pengadilan Agama di daerah-daerah, sehingga para hakim yang menjadi moderator mendapat wawasan yang cukup untuk melaksanakan mediasi, para hakim mediator diharapkan untuk mempelajari lebih dalam mengenai mediasi. Mengingat waktu yang digunakan untuk mediasi dengan moderator dari dalam pengadilan hanya 40 hari, maka diharapkan para hakim mediator dapat menyusun strategi yang tepat sehingga lebih bisa memanfaatkan waktu dengan baik.

\section{PENUTUP}

\section{Kesimpulan}

a. Kewenangan Pengadilan Agama dalam pengangkatan mediator non hakim pada Berdasarkan Peraturan Mahkamah Agung Nomor 1 Tahun 2016 Tentang Prosedur Mediasi di Pengadilan, pada dasarnya yang menjadi mediator adalah orang yang bukan hakim yang telah mendapat dan memperoleh sertifikat mediator dari lembaga yang sudah terakreditasi oleh MA, akan tetapi
PERMA Nomor 1 Tahun 2008 memberikan kelonggaran apabila disuatu lingkungan peradilan tidak terdapat mediator bersertifikat maka yang menjadi mediator adalah hakim yang berada dalam lingkungan peradilan tersebut. Prinsip utama untuk pengangkatan mediator adalah harus memenuhi persyaratan kemampuan personal dan persyaratan yang berhubungan dengan masalah sengketa para pihak. Jika persyaratan ini telah di penuhi baru mediator dapat menjalankan mediasi.

b. Hambatan pengangkatan mediator terhadap penyelesaian perkara Pengadilan Agama, ada dua yakni; pertama, akan berhasil jika terpenuhi empat hal mengenai keberhasilan mediasi yaitu; para pihak, mediator, keluarga, advokat (jika memakai advokat). Kedua, bisa gagal jika para pihak sudah tidak ingin berdamai dan rukun kembali. Karena para pihaklah yang mengambil keputusan, berdamai atau tidak. Sebagai pihak yang netral mediator memiliki peran penting dalam proses mediasi.yang membantu para pihak dalam proses perundingan guna mencari berbagai kemungkinan penyelesaian sengketa tanpa menggunakan cara memutus 
atau memaksakan sebuah penyelesaian.

\section{Saran}

Perlu adanya tindakan lanjutan dan perhatian dari Mahkamah Agung mengenai mediasi dalam hal pelatihan dan peningkatan kompetensi mediator non hakim, karena mengingat masih belum ada pengaturan secara khusus tentang pengangkatan mediator dari luar pengadilan (mediator non hakim).

\section{DAFTAR PUSTAKA}

\section{A. Buku}

Abdul Manan, Hukum Ekonomi Syariah Dalam Perspektif Kewenangan Peradilan Agama,: Kencana, Jakarta, 2012.

Akhmad Muslih, Aktualisasi Syari'at Islam Secara Komprehensif Dalam Peradaban Manusia, Bengkulu, 2004.

Ali Budiardjo Dkk, Reformasi Hukum Di Indonesia, PT Siber Konsultan, Jakarta, 1999.

Any Nugroho, Hukum perbankan Syariah, Aswaja Pressindo, Yogyakarta, 2015.

Amran Suadi, Penyelesaian Sengketa Ekonomi Syariah Teori dan Praktik, Kencana, Depok, 2017.

Bagir Manan, Penegakan Hukum Yang Berkeadilan, Jakarta, Varia Peradilan, edisi Nopember 2005.

Bambang Sunggono, Metodologi Penelitian Hukum, PT. Raja Grafindo Persada, Jakarta, 1998.
Barda Nawawi Arief, Masalah Penegakan Hukum dan Kebijakan Hukum Pidana Dalam Penanggulangan Kejahatan, Kencana, Jakarta, 2007.

Barda Nawawi Arief, Kapita Selekta Hukum Pidana tentang Sistem Peradilan Pidana Terpadu (Integrated Criminal ustice System),Penerbit Universitas Diponegoro, Semarang, 2011.

Barda Nawawi Arief, Reformasi Sistem Peradilan ( sistem penegakan hukum) di Indonesia, Universitas Diponegoro, Semarang, 2012.

Binsar M. Gultom, Pandangan Kritis Seorang Hakim Dalam Penegakan Hukum Di Indonesai, PT. Gramedia Pustaka Utama, Jakarta, 2012.

Candra Irawan, Aspek Hukum Dan Mekanisme Penyelesaian Sengketa Di Luar Pengadilan (Alternative Dispute Resolution) Di Indonesia, Mandar Maju, Bandung, 2010.

Cik Basir, Penyelesaian Sengketa Perbankan Syariah di Pengadilan Agama dan Mahkamah Syar"iah, Kencana, Jakarta, 2009.

Edi As ${ }^{e}$ Adi, Hukum Acara Perdata dalam Perspektif Mediasi (ADR) di Indonesia, Yogyakarta, Graha Ilmu, 2012.

Fathurrahman Djamil, Hukum Ekonomi Islam Sejarah, Teori, Dan Konsep, Sinar Grafika, Jakarta, 2013.

Harri Swantoro, 2016, Strategi dan Taktik Mediasi Berdasarkan PERMA Nomorl Tahun 2016 Tentang Prosedur Mediasi di Pengadilan, Jakarta, Kencana.

Ismali, Perbankan Syariah, Prenadamedia Group, Jakarta, 2011. 
Jhony Ibrahim, Teori dan Metodelogi Penelitian Hukum Normatif, Bayu Media, Malang, 2006.

Khamimudin, Kiat dan Teknis Beracara di Pengadilan Agama, Yogyakarta, Gallery Ilmu, 2010.

Khotibul Umam, Penyelesaian Sengketa diluar Pengadilan, Penerbit Pustaka Yustisia, Yogyakarta, 2010.

Laica Marzuki, Berjalan-jalan Di Ranah Hukum, Sekretaris Jenderal \& Kepaniteraan Mahkamah Konstitusi RI, Jakarta, 2006.

Mardani, Hukum Ekonomi Syariah Di Indonesia, PT Refika Aditama, Jakarta, 2011.

Nurnaningsih, Amrian, Mediasi Alternatif Penyelesaian Sengketa Perdata di Pengadilan, Jakarta, Raja Grafindo Persada, 2012.

Rachmadi Usman, Mediasi di Pengadilan dalam Teori dan Praktik, Sinar Grafika, Jakarta, 2012.

Ronald. S. Lumbuan, PERMA RI Wujud Kerancuan Antara Praktik Pembagian dan Pemisahan Kekuasaan, Jakarta, Raja Grafindo Persada, 2011.

Muslan Abdurrahman, Sosiologi dan Metode Penelitian Hukum, UMM Press, Malang, 2006.

Soerjono Soekanto, Kesadaran Hukum dan Kepatuhan Hukum, Rajawali Press, Jakarta, 2003.

Soerjono Soekanto, Sosiologi Suatu Pengantar, Raja Grafindo Persada, Jakarta, 2009.
Sudikno Mertokusumo, Mengenal Hukum Suatu Pengantar, Cahaya Atma Pustaka, Yogyakarta, 2010.

Suhrawardi \& Farid Wajdi, Hukum Ekonomi Islam, Sinar Grafika, Jakarta, 2012.

Soerjono Soekanto, Faktor-Faktor Yang Mempengaruhi Penegakan Hukum, Rajawali Pers, Jakarta, 2012.

Soerjono Soekanto, Suatu Tinjauan Sosiologi Hukum Terhadap Masalah-Masalah Sosial, Alumi Bandung, 2012.

Soerjono Soekanto dan Sri Mamudji, Penelitian Hukum Normatif, Rajawali Pers, Jakarta, 2014.

Syahrizal Abbas, Mediasi Dalam Perspektif Hukum Syariah, Hukum Adat dan Hukum Nasional, Jakarta : Kencana, 2011.

Syukri Iska, System Perbankan Syariah Di Indonesia Dalam Perspektif Fikih Ekonomi, Yogyakarta, Fajar Media Press, 2012.

Takdir Rahmadi, Mediasi Penyelesaian Sengketa Melalui Pendekatan Mufakat, Jakarta : RajaGrafindo, 2010.

Teguh Sulistia \& Aria Zurnetti, Hukum Pidana Baru Pasca Reformasi, Rajawali Pers, Jakarta, 2011.

Zainunddin Ali, Sosiologi Hukum, Sinar Grafika, Jakarta, 2007.

Witanto, Hukum Acara Mediasi Dalam Perkara Perdata di Lingkungan Peradilan Umum dan Peradilan Agama Menurut PERMA Nomor1 Tahun 2008 Tentang Prosedur Mediasi di Pengadilan, Alfabeta, Bandung, 2012. 
Majalah Hukum, Varia Peradilan Tahun XXXI Nomor 361 Desember 2015, Ikatan Hakim Indonesia (IKAHI), Jakarta.

Majalah Hukum, Varia Peradilan Tahun XXXI Nomor 363 Februari 2016, Ikatan Hakim Indonesia (IKAHI), Jakarta.

Majalah Hukum, Varia Peradilan Tahun XXXI Nomor 362 Januari 2016, Ikatan Hakim Indonesia (IKAHI), Jakarta.

\section{B. Peraturan Perundang-Undangan}

Undang-Undang Nomor 48 Tahun 2009 tentang Kekuasaan Kehakiman.

Peraturan Mahkamah Agung Republik Indonesia Nomor 1 Tahun 2008 tentang Prosedur Mediasi.
Peraturan Mahkamah Agung Republik Indonesia Nomor 1 Tahun 2016 Tentang Prosedur Mediasi Di Pengadilan.

Peraturan Mahkamah Agung Republik Indonesia Nomor 14 Tahun 2016 Tentang Tata Cara Penyelesaian Perkara Ekonomi Syariah. 